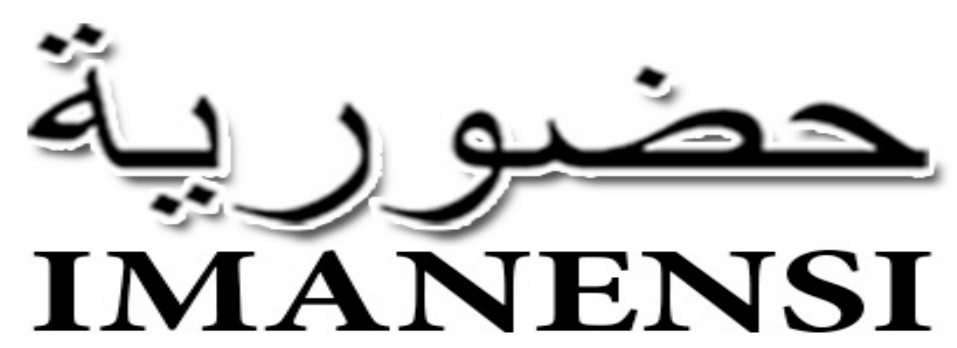

(Jurnal Ekonomi, Manajemen, dan Akuntansi Islam)

Vol 3, No 2, September 2018, Hlmn. 19-30

\title{
Pajak penghasilan bagi profesi penulis: kehebohan sesaat di dunia maya
}

\section{Dian Purnama Sari}

Universitas Katolik Widya Mandala Surabaya, J1. Kalisari Selatan No.1, Surabaya, Indonesia 60112

Dian-ps@ukwms.ac.id

doi: 10.34202 /imanensi.3.2.2018.19-30

\begin{abstract}
Abstrak
Pajak merupakan bukti bakti masyarakat kepada Negara. Namun, bagi masyarakat, pembayaran pajak masih terasa sebagai "paksaan" layaknya upeti kepada Negara. Hal ini terlihat dari tulisan dan kritik yang disampaikan oleh beberapa penulis terkenal di Indonesia. Pemotongan pajak penghasilan bagi profesi penulis dirasa tak adil oleh penulis di Indonesia. Tulisan ini ingin membandingkan pajak penghasilan yang harus dibayar sesuai dengan beberapa masukan dari profesi penulis dengan peraturan perpajakan yang ada. Hasil tulisan ini menunjukkan bahwa pembayaran pajak penghasilan penulis sesuai dengan peraturan pemerintah merupakan pemotongan pajak yang adil.
\end{abstract}

Kata Kunci: Pajak Penghasilan; Pekerjaan Bebas; Penulis.

\section{Abstract}

Tax is a society loyalty to government. Altough, to majority people, tax feel like enforcement. There are so many critics about tax, including famous book author in Indonesia. Income tax deduction is unfair according to author. This study aims to compare income tax with tax regulation and recommendation from author. The result show that amount of income tax with tax regulation are fair enough.

Keywords: Income Tax; Freelance; Author.

This is an open access article under the CC-BY-SA license.

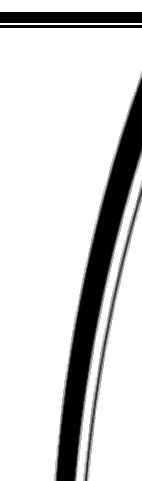


Baru-baru ini dunia literasi di Indonesia dihebohkan dengan munculnya "protes" keras seorang penulis yang cukup terkenal di tanah air. Seorang Penulis, sebut saja TR, menuliskan curahan hati yang cukup panjang di media sosialnya mengenai ketidakadilan pajak yang dirasakannya sebagai seorang penulis. Sang penulis menjelaskan hitungan-hitungan pajak dari beberapa profesi yang disebutkan dan menunjukkan betapa pajak yang dikenakan bagi penulis jauh lebih tinggi ketimbang kepada profesi yang lain. Protes ini ditindaklanjuti dengan diberhentikannya cetakan buku hardcopy dari sebuah penerbit ternama. Sebagai seorang penulis terkenal, maka tulisannya pun menuai banyak komentar dari para pengikutnya di media sosial. Banyak netizen di dunia maya yang langsung turut berkomentar dan akhirnya banyak pula yang mempertanyakan "ketidakadilan" pajak tersebut. Maklum, netizen di Indonesia merupakan netizen yang memang cukup aktif dalam dunia maya, khususnya di media sosial. Perang komentar pun terjadi di dunia maya. Namun, yang patut disayangkan dengan perang komentar di dunia maya adalah seringkali banyak yang belum paham terhadap sesuatu namun turut berkomentar dan merasa menjadi "pakar" dadakan. Maka isu bahwa pajak tidak adil bagi penulis semakin tergoreng dengan nikmatnya.

Kehebohan ini terus berlanjut ketika ada seorang penulis terkenal kembali yang turut menyuarakan "ketidakadilan" pajak bagi penulis. Penulis ini, sebut saja DL, turut menyuarakan ketidakadilan pajak, tetapi lebih khusus disebutkan masalah royalti. Sang penulis, DL, menyebutkan bahwa selama ini royalti yang diperoleh oleh penulis adalah merupakan penghasilan utama, maka selayaknya masuk dalam penghasilan utama bagi seorang penulis. Namun, royalti bagi penulis dalam perpajakan dianggap sebagai objek Pajak Penghasilan (PPh) pasal 23 yang tidak dapat dipotong dengan Norma Perhitungan Penghasilan Neto (NPPN). Penulis juga menyayangkan bahwa pajak terkadang tidak menilai "ide" yang tertuang dalam buku yang berasal dari proses yang panjang bagi seorang penulis yang seharusnya dapat dihargai sebagai "modal" kerja seorang penulis.

Isu ini langsung ditanggapi oleh Menteri Keuangan, Sri Mulyani, dan ditindaklanjuti oleh Dirjen Pajak dengan mengeluarkan. Dirjen Pajak juga melakukan sosialisai ke KPP agar dapat memberikan informasi yang aktual saat berhadapan dengan Wajib Pajak Orang Pribadi (WPOP) yang berprofesi seorang penulis. Surat edaran pun telah dipublikasikan. Namun, apa daya, seringkali informasi yang pertama diperoleh dan viral di media sosial telah diamini oleh banyak orang. Tugas berat menanti Dirjen Pajak dalam memberikan pemahaman dan pengetahuan bagi masyarakat Indonesia agar informasi yang belum seluruhnya benar tidak terlanjur diterima. Pemahaman ini penting agar budaya membayar pajak tidak menjadi kendor karena informasi yang menyiratkan bahwa perlakuan pajak seringkali tidak adil bagi pembayar pajak. Budaya membayar pajak yang sedang didengungkan Dirjen Pajak akan menjadi lebih sulit terealisasi apabila masyarakat sudah enggan dan memiliki persepsi negatif terhadap dunia perpajakan Indonesia.

Persepsi masyarakat yang negatif terhadap dunia perpajakan Indonesia turut menurunkan kemauan Wajib Pajak (WP) untuk membayar pajak secara benar (Sari, 2011). Kesadaran WP merupakan kunci bagi WP untuk mau membayar pajak. Pengetahuan WP terhadap peraturan perundang-undangan yang berlaku membuat WP untuk lebih paham dan akhirnya dapat membayar pajak sesuai dengan peraturan. Kesadaran dan pengetahuan WP memang seringkali berpengaruh terhadap kepatuhan WP dalam membayar pajak (Erawati \& Parera, 2017; Yusdinar dkk., 2015). Seorang WP haruslah memiliki niat dalam membayar pajak, membiasakan diri sebagai WP yang patuh dengan membayar pajak tepat waktunya. WP harus memiliki pemahaman yang baik tentang pajak agar bisa menjalankan kewajibannya sesuai dengan Undang-Undang Perpajakan yang berlaku sehingga budaya membayar pajak menjadi kebiasaan yang baik bagi seluruh masyarakat Indonesia.

Tulisan ini ingin menelisik dan menggali kebenaran "ketidakadilan" pajak yang didengungkan oleh penulis di Indonesia. Tujuan tulisan ini adalah ingin menggali dari sisi Undang-Undang (UU) Perpajakan Indonesia untuk profesi penulis sehingga tidak terjadi kesimpangsiuran pemahaman mengenai perlakuan pajak kepada profesi penulis. Tulisan ini juga ingin membawa penyadaran bagi masyarakat agar sebaiknya 
informasi dikaji terlebih dahulu baru kemudian dapat dipahami dan dipercaya sebagai sebuah kebenaran.

\section{HASIL DAN PEMBAHASAN}

Pajak bagi profesi Penulis menurut TR. TR adalah seorang penulis terkenal yang telah menelurkan banyak buku best seller dan menjadi salah satu idola dalam dunia literasi di Indonesia. Secara mengejutkan, sang penulis memutuskan untuk menghentikan penerbitan 28 buku (hardcopy) per 31 Juli 2017. Tindakan ini dilakukan karena sang penulis merasa pemotongan Pajak Penghasilan ( $\mathrm{PPh}$ ) bagi profesi penulis tidaklah adil. Pemotongan $\mathrm{PPh}$ bagi penulis dirasa paling tinggi di antara beberapa profesi lain yang sama-sama pekerjaan bebas ataupun mereka yang berprofesi sebagai karyawan ataupun mereka yang pengusaha UMKM. Isi note yang dipublikasikan melalui media sosial pada tanggal 6 September 2017 secara lengkap adalah sebagai berikut:

\section{Jalan keluarnya selalu ada}

Kalian harus tahu, penulis buku adalah orang yang paling dermawan kepada Negara. Kalian harus sopan sekali kepada penulis buku, karena dia membayar pajak lebih banyak disbanding kalian semua. Eh, saya serius lho, tidak sedang bergurau.

Di sebuah komplek misalnya, ada 10 rumah, Rumah A adalah dokter, Rumah B adalah akuntan, Rumah C adalah arsitek, Rumah D adalah pengusaha, Rumah $\mathrm{E}$ adalah pengacara, Rumah $\mathrm{F}$ adalah karyawan swasta, Rumah G adalah PNS, Rumah $\mathrm{H}$ adalah artis terkenal, Rumah I adalah motivator dan Rumah $\mathrm{J}$ adalah penulis buku. Maka penulis buku adalah orang yang membayar pajak paling banyak.

Kita anggap saja 10 rumah ini semuanya sama penghasilnnya: 1 Milyar/tahun. Dan kita anggap saja PTKP (Penghasilan Tidak Kena Pajak) rumah ini sama - jadi kita anggap PTKP-nya nol saja, untuk memudahkan ilustrasi.

Maka dokter (A), akuntan (B), arsitek (C), artis terkenal (H), motivator (I) pajaknya dihitung sbb: 1 Milyar X 50\% (Rasio NPPN, kurang lebih demikian rasionya, biar sederhana), dapatlah 500 juta penghasilan netto. LAntas dikalikan lapisan (layer) pajak penghasilan progresif, 5 juta pertama tarifnya $5 \%$, 50-250 juta berikutnya tarifnya $15 \%$, lantas $250-500$ juta berikutnya tarifnya $25 \%$. Total pajak rumah-rumah ini adalah hanya 95 juta.

Sementara rumah D, karena dia adalah pengusaha UMKM, maka tariff pajaknya hanya $1 \%$ dari omzet bruto. Rp 1 Milyar x $1 \%=\mathrm{Rp} 10.000 .000$. Selesai. Mudah menghitungnya. Tentu, mengingat sifatnya bisnis, belum tentu $1 \mathrm{M}$ tadi adalah penghasilan bersih, karena dia harus membeli bahan-bahan, dan lain-lain. Tapi tetap saja, pajak mereka murah sekali, hanya $1 \%$.

Lantas penulis buku, berapa pajaknya? Karena penghasilan penulis buku disebut royalti, maka apa daya, menurut staf pajak, penghasilan itu semua dianggap super netto. Tidak boleh dikurangkan dengan rasio NPPN ${ }^{1}$, pun tidak ada tariff khususnya. Jadilah pajak penulis buku: 1 milyar dikalikan dengan layer tadi langsung, 50 juta pertama tarifnya 5\%, 50-250 juta berikutnya tarifnya $15 \%$, lantas 250-500 juta berikutnya tarifnya 25\%. Dan 500-1 milyar berikutnya $30 \%$. Maka total pajaknya adalah Rp 245 juta.

Lihat perhitungannya? Penulis buku membayar pajak 24X disbanding pengusaha UMKM dan $2 \mathrm{x}$ lebih dibandingkan profesi pekerjaan bebas. Dan jangan lupakan lagi, penulis itu pajaknya dipotong oleh penerbit, itu artinya, dia tidak bisa menutup-nutupi pajaknya. Artis, pengusaha, lawyer, wah, itu sih

\footnotetext{
${ }^{1}$ Norma Perhitungan Penghasilan Neto
} 
mudah sekali untuk menyembunyikan berapa penghasilan sebenarnya. Penulis tidak bisa, sekali dipotong penerbit, maka bukti pajaknya akan masuk dalam system.

Masih ada yang menyamai pajak penulis buku, yaitu karyawan swasta dan PNS. Dari angka 1 Milyar tadi, mereka dikurangi dulu biaya jabatan 5\%, lantas dikalikan layer-layernya, pajak karyawan swasta/PNS kurang lebih 5\% lebih rendah dibanding penulis. Tapi catat baik-baik, penulis adalah profesi pekerjaan bebas, dia bukan karyawan tetap. Beda sekali sifatnya. Penulis bisa sukses, bisa gagal, bukunya bisa laku, bisa tida, penghasilan bisa ada, lebih banyak tidaknya, tapi karyawan swasta dan PNS, gajinya pasti, tetap sifatnya, dan diberikan oleh perusahaan tempat dia bekerja.

Nah, dengan ilustrasi tersebut, dari 10 rumah di komplek itu: penulis buku adalah yang paling dermawan kepada pemerintah (meski rumahnya paling kecil, mobilnya paling sederhana). Mereka ternyata membayar pajak dengan jumlah massif sekali.

Apakah pemerintah tahu permasalahan ini? Tahu. Saya sudah setahun terakhir menyurati banyak lembaga resmi pemerintah, termasuk Dirjen Pajak, Bekraf, meminta pertemuan, diskusi. Mengingat ini adalah nasib seluruh penulis di Indonesia. Literasi adalah hal penting dalam perabadan. Apa hasilnya? Kosong saja. Bahkan surat-surat itu tiada yang membalas, dibiarkan begitu saja nampaknya. Atas progress yang sangat lambat tersebut, dan tiadanya kepedulian orang-orang di atas sana, maka saya TR, memutuskan menghentikan menerbitkan buku di penerbit-penerbit, Gramedia Pustaka Utama dan Penerbit Republika, per 31 Juli 2017 lalu. 28 buku-buku saya tidak akan dicetak ulang lagi, dan dibiarkan habis secara alamiah di buku hingga Desember 2017. Minggu-minggu ini, kalau kalian ke toko, toko-toko buku Gramedia sedang massif menjualnya, membuat display khusus, dll, agar semakin cepat habis. Per Januari 2018, kalian tidak akan lagi menemukan buku-buku itu di toko buku. Jika masih ada toko buku yang menjualnya, itu berarti bajakan, my friend. Lagi-lagi, sudah pajaknya besar, buku bajakannya juga banyak sekali.

Menghentikan menerbitkan buku, bukan berarti saya berhenti menulis. Tenang saja, penulis itu tugasnya menulis, jadi bahkan ketika tidak lagi diterbitkan, dia tetap bisa menulis. Naskah-naskah baru akan diposting lewat page facebook ini, atau cara-cara lain agar pembaca tetap bisa menikmati buku tersebut tanpa harus berurusan dengan pajak yang berkali-kali lipat tingginya. Saya akan memikirkan model bisnis berbeda, atau pendekatan berbeda, sepanjang itu belum ditemukan, dibagikan gratis di page ini bisa jadi solusi yang baik.

Saya selalu percaya, selalu ada jalan keluarnya. Mungkin tidak ada solusinya di pajak sana - karena boleh jadi mereka tidak paham buku adalah kunci peradaban, mereka tetap akan mengotot penulis harus bayar pajak lebih tinggi dibanding artis, dkk; tapi terus menulis dan pembaca terus bisa menikmatinya. Kecuali jika besok lusa, bahkan menulis di page facebook inipun juga kena pajak. Demikianlah. Salam literasi.

** Ilustrasi di atas adalah penyederhanaan, karena PTKP, tanggungan, biaya jabatan maksimal, donasi wajib agama, dll bervariasi setiap orang, tapi kalaupun dimasukkan semuanya secara akurat, substansinya akan sama dengan ilustrasi.

Tulisan yang berjudul jalan keluarnya selalu ada menuai banyak komentar dan disukai oleh banyak pengikutnya di laman facebook sang penulis. Banyak yang ikut berkomentar masalah "ketidakadilan" yang disuarakan oleh sang penulis TR. Ada yang membahas masalah penerbitan buku yang berhenti, ada yang menyoroti tentang 
pajak dari sisi yang pemahaman, ada pula yang langsung menghujat tentang pajak. Komentar seperti "Pajak = Palak" atau komentar lain "Itu Pemerintah atau Pengemis coba... Gimana orang Indonesia bisa pinter kalau nasib Penulis aja ga diperhatikan. gondok juga jadinya." Ataupun komentar yang berbeda lagi, "Memang sadis pajak tuh.. yang berkeringat siapa seenak nya aj motong pajak.". Tulisan penulis TR mengenai pajak akhirnya menimbulkan persepsi-persepsi bagi pembacanya. Banyak di antara mereka yang akhirnya menuliskan pendapat mereka yang menunjukkan keengganan mereka terhadap pajak, dan lebih lanjut "membenci" pajak.

Tulisan yang telah terlanjur viral tersebut tentu membawa persepsi negatif terhadap dunia perpajakan Indonesia yang sedang banyak berbenah. Slogan gencar dari Dirjen Pajak, "Membayar Pajak, Bukti Cinta Tanah Air" dirasa menjadi kabur jika melihat adanya ketimpangan dalam memotong pajak kepada masyarakat.

Penulis DL: Solusi Pajak bagi Profesi Penulis dari Sudut Pandang Penulis._Penulis DL turut berkomentar setelah penulis TR memutuskan berhenti menerbitkan buku karena permasalahan pajak. Pada tanggal 7 September 2017, DL menuliskan status di laman facebook-nya mengenai pajak bagi profesi penulis:

\section{Royalti dan Keadilan}

Enam belas tahun lalu, saat saya mulai menerbitkan buku, persepsi umum tentang profesi penulis adalah miskin dan prihatin. Banyak yang bingung kenapa saya mau banting setir dari penyanyi yang konon lebih banyak uangnya. Tak terhitung saya mendengar kasus penulis dikadali penerbit, juga penulis-penulis yang harus sibuk cari kerjaan sampingan karena tidak bias mengandalkan royalty bukunya. Seorang teman berkata, "Saya buruh kata. Kalau tidak begitu, nggak makan." Publik boleh mengenalnya sebagai novelis kenamaan, tapi sebenarnya ia mengerjakan macam-macam, dari mulai artikel pesanan, ghost writer sampai skrip iklan.

Ketika masyarakat berteriak-teriak soal memprihatinkannya budaya membaca dan kerdilnya industri perbukuan Indonesia, kami para penulis ikut teriak. Tapi, begitu urusan royalti, diskusi antarpenulis seringnya kembali kepada consensus (sekaligus penghiburan) bahwa menulis adalah urusan kepuasan batin karena membahas royalti terlalu menyakitkan.

Enam belas tahun berjalan, dan kini saya bias bilang bahwa menulis buku adalah profesi utama yang bias saya andalkan dan saya bias hidup berkecukupan. Namun, saya sadar, hanya segelintir penulis bisa menyatakan hal serupa. Mungkin jumlahnya kini lebih banyak dibandingkan tahun 2001 ketika saya baru memulai. Tapi, gambar besarnya masih sama. Secara ekonomi, penulis adalah profesi yang menantang.

Genggamlah sebuah buku dan bayangkan bahwa 90\% dari harga banderol yang Anda bayar adalah untuk aspek fisiknya saja. Hanya 10\% untuk idenya (bisa $12,5-15 \%$ kalau punya bargaining power ekstra). Lalu, penulis berhadapan dengan Negara. Potongan kue kami yang mungil itu dipotong lagi lima belas persesn, tak peduli kami hidup seperti burung hantu, wara wiri untuk riset, merogoh kocek untuk 365 cangkir kopi per tahun, atau apapun juga. It's done deal. Kami tidak akan pernah mengecap seratus persen penerimaan royalti karena pemotongan itu bersifat langsung. Lalu, sisanya kami masukkan ke dalam pendapatan tahunan. Bulat utuh menjadi pendapatan kena pajak dan masih harus menghadapi hitungan pajak berjenjang.

Setelah penulis "TR" memutuskan untuk menarik 28 bukunya dari penerbit sebagai protes terhadap kebijakan pajak royalti penulis, hangatlah diskusi di berbagai ranah. Berbagai tanggapan pun muncul, dari pengamat pajak, Dirjen Pajak, bahkan Ibu Sri Mulyani ikut bersuara. Beberapa respons mengatakan keputusan Tere Liye emosional dan berbasiskan persepsi yang kurang tepat mengenai pajak royalti. 
Saya bukan pakar pajak. Saya berbicara dari sudut pandang sesama penulis dan wajib pajak biasa. Saya juga tidak mengenal "TR" secara langsung. Tapi, saya bisa pastikan TR tidak sendiri dalam kegelisahannya. Setiap ada kesempatan berbicara mewakili penulis, soal pajak royalti tidak pernah luput saya ungkap. Termasuk ketika saya punya kesempatan curhat langsung kepada Presiden Jokowi di acara Temu Kreatif BEKRAF di ICE BSD, tahun 2015. Di sana, kembali saya menyuarakan agar pajak royalti penulis diringankan.

Dengan seorang pejabat pajak, saya pernah berdiskusi panjang lebar. Dalam pandangan awam saya, peraturan pajak saat itu rasanya menggasak penulis dua kali. Sudah pendapatan royalti dikenai $15 \%$, pendapatan bruto yang masuk ke penghasilan tahunan dihitung utuh sebagai pendapatan kena pajak. Saya lalu membandingkan dengan suami saya, seorang praktisi kesehatan, yang karena profesinya dapat menggunakan rumus norma sebesar $30 \%$. Dari total pendapatannya, ia cukup memasukkan 30\% untuk dikenai pajak. Sisanya? Dianggap sebagai modal usahanya sebagai praktisi kesehatan.

Dalam diskusi itu saya bertanya, mengapa tidak ada norma untuk profesi penulis? Mengapa pendapatan kami seratus persen dikenai pajak? Lalu, pejabat pajak itu menjawab, norma hanya rumus untuk memudahkan. Jika saya mau membuat pembukuan, bisa saja saya masukkan biaya-biaya yang dianggap "modal menulis", entah itu sewa kantor, riset dan sebagainya.

Saya pun berpikir, mengapa pnulis harus serepot itu mengada-ada agar mendapatkan keringanan? Meulis buku saja sudah repot. Dan, setelah saya telusuri lagi, melampirkan pembukuan pun bukan solusi bagi profesi penulis karena penghasilan royalti dianggap sebagai income pasif, macam bunga deposito. Namun, yang paling mengganggu saya saat itu adalah, ketiadaan norma bagi penulis menunjukkan bahwa profesi kami masih invisible di mata pajak.

Setahun setelah curhat saya ke Presiden Jokowi, saya mendengar kabar baik dari Yustinus Prastowo, analis pajak yang sering saya ajak tukar pikiran, bahwa aka nada aturan norma untuk penulis. Akhirnya. Profesi penulis memiliki tempat bersama-sama profesi-profesi lain yang punya pilihan memakai rumus norma. Kami, yang tidak punya staf akuntan dan tak sempat membuat pembukuan apalagi mengarang-ngarang pengeluaran modal, dapat dimudahkan dengan rumus norma ini. 50\%. Not bad, pikir saya. Daripada tidak sama sekali.

Tahun 2017 ini akhirnya kami berkesempatan menggunakannya. Saya bahkan sebarkan kabar bahagia itu ke rekan-rekan penulis di awal bulan pelaporan pajak agar mereka tidak lupa menggunakan privilese baru tersebut. Namun, ternyata tidak semua berakhir baik. Beberapa teman melaporkan bahwa pemakaian norma mereka ditolak oleh KPP setempat. Alasannya, norma itu hanya bisa dipakai untuk pendapatan non-royalti. Saya ikut terkejut. Pendapatan utama seorang penulis seharusnya adalah royaltinya. Jadi, kenapa justru norma itu tidak bisa dipakai untuk pendapatan utamanya?

Saya pikir tadinya itu sekadar masalah sosialisasi. Mungkin belum semua KPP paham dan ngeh tentang aturan baru itu. Di sinilah akhirnya polemik "TR" memberikan saya kejelasan. Akibat maraknya pembahasan pajak royalti penulis, saya berkesempatan mengumpulkan berbagai perspektif. Dan, ternyata saya masih menemukan akar permasalahan yang sama.

Ketika penulis dianggap memperoleh penghasilan pasif, maka ia tidak dianggap layak untuk memanfaatkan rumus norma. Penulis dianggap tidak keluar modal. Biaya kertas, percetakan, distribusi, dsb, adalah modal penerbit. Terkecuali jika penulis menerbitkan sendiri karyanya, barulah ia dianggap keluar modal. Artinya, ketika pajak menggenggam sebuah buku, ia hanya melihat modal yang keluar dari 90\% aspek fisik buku saja, bukan dari kontennya.

Inilah masalahnya. Terlepas dari definisi royalti per se, bagi saya pada hakikatnya penerbit dan penulis seperti mitra yang berbagi hasil. Mereka membawa 
investasinya sendiri-sendiri. Penerbit membawa modal cetak. Penulis membawa modal konten dan waktu yang telah ia dedikasikan untuk mewujudkan idenya menjadi buku. Buku laku maka dua-duanya untung. Buku tak laku maka duaduanya bunting.

Di mata pajak, definisi modal masih berkutat di aspek fisik mekanis. Ada wujudnya, ada barangnya. Sementara modal penulis bersifat abstrak. Secara wujud fisik, penulis mungkin dating hanya dengan membawa sebatang USB atau jilidan draf. Tak ada harganya. Tapi. Sebagai pihak yang melalui proses berkarya, bagi saya modal itu tidak kecil sama sekali. Penulis adalah hulu dari indutri buku. Penyumbang konten yang lalu diperbanyak secara fisik oleh mata rantai berikutnya. Bagaimana mungkin kontribusi di hulu itu tidak dihargai secara proposional?

Kalau rumus norma penulis hanya berlaku bagi pendapatan non-royalti, maka untuk menikmatinya penulis harus mengkapitalisasi lagi kepenulisannya sebagai pembicara, pemateri, pengiklan. Apa pun tapi bukan royalti. Boleh-boleh saja tentunya. Saya pun melakukannya. Tapi, berapa banyak penulis yang punya kesempatan ke sana? Dan apa gunanya norma 50\% itu kalau ternyata tidak bisa menyentuh pendapatan utama penulis, yakni royalti bukunya sendiri? Lagi-lagi, kondisi tadi menggarisbawahi bahwa: menulis buku saja tidak cukup.

Setiap saya memasuki periode menulis buku baru, ada satu folder yang akan sering sekali saya buka. Isi folder itu adalah template surat penolakan. Saya menolak tawaran jadi pembicara, menolak undangan ke luar kota, dsb. Rangkaian penolakan tersebut bisa berlangsung enam bulan hingga setahun. Saya sadar banyak peluang income yang terpaksa saya lewatkan demi melahirkan buku baru, but I set my priority. Ketika suami pergi kerja dan anak saya sekolah, saya menghabiskan 5-7jam per hari untuk menulis.

Di Inggris, penulis macam saya termasuk kategori pekerja lepasan, dan untuk itu pendapatannya dianggap sebagai pendapatan aktif. Namun, di mata perpajakan kita, semua yang saya lakukan itu adalah upaya pasif. Pemasukan saya kelak juga akan menjadi pendapatan pasif. Sama seperti kalau saya mendepositokan uang, mendiamkannya, dan menunggu ia tumbuh. Masalahnya, buku saya tidak menulis dirinya sendiri. Saya yang aktif bekerja melakukannya. Bisa setahun penuh. Hasil dari kerja itulah yang menjadi modal saya untuk pergi ke penerbit dan bernegosiasi. Dan apakah berhenti di sana? Tentu tidak. Kami masih harus menjalani program promosi berupa launching, booksigning, jumpa pembaca, dst.

Pertanyaan saya, jika memang pekerjaan kami dianggap pasif, mengapa perlakuan pajak terhadap pendapatan royalti tidak mencerminakan itu? Bunga deposito dikenai pajak final. Tetapi, pendapatan royalti tidak demikian. Betul, pajak yang tidak final bisa digunakan sebagai kredit pajak, dan itu yang selalu menjadi alas an ketidakfinalan pajak royalti dianggap "menguntungkan". Tapi, silahkan simulasi sendiri. Mana yang lebih punya dampak bagi kami. Dikenai pajak dua kali atau sekalian jadikan pajak royalti sebagai pajak final? Karena toh setelah profesi penulis punya rumus norma sekalipun, kami tetap tidak dapat menggunakannya untuk meringankan pajak royalti kami.

Ketidakselarasan antara perlakuan profesi dan perlakuan pajak inilah yang menjadi sumber masalah. Porsi jerih payah kami mungkin hanya $10-15 \%$ dari harga banderol, tapi jangan nolkan modal kami. Selama kontribusi kami tidak dilihat sebagai modal riil, maka selamanya pula kami dirugikan meski dengan adanya pilihan memakai norma.

Ketika saya bicara soal meminta keringanan pajak royalti, beberapa berkomentar, "Orang pajak pasti akan bertanya balik, keuntungan buat mereka apa? Kalau pajak diringankan, harus ada timbal baliknya." Saya mengerti logikanya, tapi juga mendapatkan hal itu menyedihkan. Kalau hitungannya cuma uang, saya tidak tahu bisa memberi timbal balik apa lagi untuk pemerintah (selain berkarya dan 
membayar pajak). Bahkan dalam peta ekonomi kreatif Indonesia, industri perbukuan adalah industri bontot yang kuenya sangat kecil dibandingkan kuliner dan busana.

Saya juga tidak mau terdengar cengeng dan minta diistimewakan, sebagaimana saya pun yakin bukan itu motivasi Tere Liye lewat protesnya, tapi kenyataannya industri buku dengan penulis sebagai hulunya memang masih perlu disokong.

Jika kita sungguh-sungguh ingin meningkatkan mutu literasi bangsa ini, jika kita ingin punya lebih banyak penulis berkualitas yang melahirkan buku-buku bermutu, jika kita betulan kepengin menjadi bangsa pencipta dan bukan hanya penadah, kita harus mulai melihat jenis modal lain selain modal fisik mekanis.

Mulailah berpikir tentang investasi kreativitas dan intelektualitas. Ketika profesi penulis bisa menjadi salah satu profesi yang menguntungkan secara ekonomi, saya yakin akan lebih banyak orang yang berani berdedikasi pada kepenulisannya. Penulis dapat fokus berkarya sebaik mungkin tanpa harus dipusingkan menyambi kiri-kanan demi menyambung hidup. Penulis berkesempatan sepenuhnya bersandar pada buku yang ia tulis tanpa harus memutar otak mengkapitalisasi dirinya demi memperbanyak pendapatan non-royalti. Tidakkah kesejahteraan penulis adalah bagian dari mimpi besar memperbaiki kondisi literasi bangsa ini?

DJP telah memberikan pernyataan resmi sehubungan isu pajak royalti penulis. Di paragraf akhir tertera keterbukaan DJP untuk menerima masukan. Sekali lagi, saya bukan pakar pajak. Tapi, izinkan saya memberi sedikit masukan. Ini hanya harapan berdasarkan nalar, yang syukur-syukur menjadikan wacana keringanan pajak royalti penulis yang kami maksud bisa tepat sasaran:

- Jika royalti tetap dianggap penghasilan pasif, maka perlakukanlah pajaknya seperti pemasukan pasif. Final. Setelah penerbit memotong pajak kami, maka selesai urusan.

- Jika royalti bisa dipertimbangkan sebagai penghasilan aktif, maka beri pilihan penggunaan norma pada seluruh pendapatan kami tanpa kecuali.

Jujur, pilihan pertama lebih menggairahkan bagi saya. Bayangkan, jika para kreator diberi keleluasaan seperti itu, negara benar-benar dapat menghadirkan atmosfer kondusif bagi para penemu dan insan kreatif yang pekerjaannya mencipta, termasuk penulis.

Andai perubahan kebijakan pajak yang kami harapkan terjadi, mungkin tidak serta merta pula bermunculan penulis kaya raya. Kembali kepada konsensus/penghiburan kami, menulis pada dasarnya adalah merayakan kepuasan batin. Namun, ketika kerja keras kami menjadi kasat mata di mata pajak, terlepas jadi best-seller atau tidak, kami punya satu bahan lagi untuk dirayakan. Keadilan.

Ini curahan hati sesama penulis terkenal Indonesia yang juga menyoroti "keadilan" bagi penulis dalam membayar pajak di laman facebook nya. Tulisan DL lebih banyak lagi menuai pro dan kontra masalah pajak. Pembahasan pajak bagi profesi penulis di media sosial semakin massif dan menimbulkan banyak persepsi. Lalu bagaimana sebenarnya perlakuan pajak bagi profesi penulis di mata UndangUndang Perpajakan Indonesia?

Memahami Profesi Penulis di Mata Undang-Undang Perpajakan Indonesia. Undang-Undang Ketentuan Umum Perpajakan (UU KUP) pasal 1 ayat (24) menyatakan bahwa pekerjaan bebas adlah pekerjaan yang dilakukan oleh orang pribadi yang mempunyai keahlian khusus sebagai usaha untuk memperoleh penghasilan yang tidak terikat oleh suatu hubungan kerja. Lebih lanjut dalam Peraturan Direktur Jenderal Pajak dalam PER-32/PJ/2015 pasal 3 huruf C atau 
disebutkan pula dalam penjelasan PP no 46 tahun 2013, bahwa pekerjaan bebas meliputi:

1. Tenaga ahli yang melakukan pekerjaan bebas, yang terdiri dari: pengacara, akuntan, arsitek, dokter, konsultan, notaris, penilai dan aktuaris.

2. Artis: pemain musik, pembawa acara, penyanyi, pelawak, bintang film, bintang sinetron, bintang iklan, sutradar, kru film, foto model, peragawan/peragawati, pemain drama dan penari.

3. Olahragawan.

4. Penasihat, pengajar, pelatih, penceramah, penyuluh dan moderator.

5. Pengarang, peneliti dan penerjemah.

6. Agen iklan.

7. Pengawas atau pengelola proyek.

8. Perantara.

9. Petugas penjaja barang dagangan.

10. Agen asuransi, dan

11. Distributor perusahaan pemasaran berjenjang (multilevel marketing) atau penjualan langsung (direct selling) dan kegiatan sejenis lainnya.

Penulis, dalam Kamus Besar Bahasa Indonesia (KBBI), dapat diartikan sebagai (1) Orang yang menulis; (2) Pengarang: naskah; dan seterusnya. Menulis dapat diartikan pula sebagai kegiatan melahirkan pikiran atau perasaan (seperti mengarang, membuat surat) dengan tulisan: roman (cerita). Tulisan dapat pula diartikan sebagai karangan (dalam majalah, surat kabar, dan sebagainya atau yang berupa cerita, dongeng dan sebagainya); buku-buku (karya-karya tulis dan sebagainya). Pengertian yang dirujuk dalam KBBI menunjukkan bahwa profesi penulis menghasilkan tulisan yang berisi pikiran atau perkataan yang dapat berupa buku. Menurut pengertian ini, maka jelaslah bahwa profesi penulis merupakan sinonim dari pengarang. Maka sudah selayaknya profesi penulis dikategorikan sebagai pekerjaan bebas.

Pekerjaan bebas disebut dalam Peraturan PER-17/PJ/2015 pasal 1 ayat (2), yaitu Wajib Pajak Orang Pribadi (WPOP) yang melakukan kegiatan usaha atau pekerjaan bebas yang peredaran brutonya dalam 1 (satu) tahun kurang dari Rp 4.800.000.000,00 (Empat miliar delapan ratus juta rupiah) wajib melakukan pencatatan, kecuali Wajib Pajak yang bersangkutan memilih menyelenggarakan pembukuan. WPOP yang dimaksud pada ayat (2) menghitung penghasilan neto dengan menggunakan Norma Perhitungan Penghasilan Neto (NPPN). Penulis, yang termasuk dalam kriteria pekerjaan bebas, layak untuk melakukan pencatatan dan menghitung penghasilan neto melalui NPPN yang tentu saja dirasa lebih memudahkan penulis dalam menghitung penghasilan neto.

Permasalahan kedua dalam profesi penulis adalah royalti. Royalti dalam KBBI, dapat diartikan sebagai uang jasa yang dibayar oleh penerbit kepada pengarang untuk setiap buku yang diterbitkan. Royalti juga dapat diartikan sebagai suatu jumlah yang dibayarkan atau terutang dengan cara atau perhitungan apa pun, baik dilakukan secara berkala maupun tidak, sebagai imbalan atas salah satunya penggunaan atau hak menggunakan hak cipta di bidang kesusastraan, kesenian atau karya ilmiah, paten, desain atau model, rencana, formula atau proses rahasia, merek dagang, atau bentuk hak kekayaan intelektual/industrial atau hak serupa lainnya. Yang menjadi pokok permasalahan dalam royalti adalah royalti seringkali dianggap sebagai penghasilan pasif. Berdasarkan Peraturan Dirjen Pajak Nomor PER33/PJ/2009 jo. SE-58/PJ/2009, royalti adalah salah satu penghasilan yang disebut dalam pasal 23 yang dipotong sebesar 15\% (lima belas persen) dari jumlah bruto. Royalti termasuk objek PPh pasal 23 karena penulis dianggap termasuk dalam pemegang hak cipta yaitu pencipta atau pihak yang menerima hak tersebut dari 
pencipta atau pihak lain yang menerima lebih lanjut hak dari pihak yang menerima hak tersebut. Sebagian penulis menganggap salah satu ketidakadilan adalah royalti dianggap sebagai penghasilan pasif, sama seperti dividen atau bunga. Padahal royalti yang diperoleh penulis seharusnya masuk dalam penghasilan aktif, di mana untuk memperoleh royalti, penulis harus bekerja keras untuk menghasilkan ide untuk penulisan bukunya. Royalti karena masuk dalam objek $\mathrm{PPh}$ pasal 23, tidak dapat dikalikan dengan NPPN namun akan menambah penghasilan bruto pada saat pengisian SPT tahunan. Namun, karena royalti dipotong PPh pasal 23, maka besaran potongan PPh pasal 23 dapat dikreditkan.

Ada beberapa saran dan masukkan dari penulis mengenai perlakuan pajak bagi profesi penulis. Pertama, memperlakukan pajak untuk profesi penulis sebesar $1 \%$ dan final. Saran ini, menurut saya, sedikit menyimpang dari kategori penulis sebagai pekerjaan bebas. Pemberlakuan tarif $1 \%$ seperti meniru perhitungan menurut PP Nomor 46 Tahun 2013. Namun, PP 46 tahun 2013 menyasar usaha kecil dan menengah yang peredaran brutonya tidak melebihi Rp 4.800.000.000 dalam 1 tahun pajak yang meliputi usaha dagang, industri dan jasa, seperti misalnya took/kios/los kelontong, pakaian, elektronik, bengkel, penjahit, warung/rumah makan, salon dan usaha lainnya. Tujuan PP Nomor 46 tahun 2013 adalah mempermudah masyarakat khususnya yang tidak memahami pembukuan agar tetap dapat melaksanakan kewajiban perpajakannya dengan baik. Namun, penghasilan dari jasa sehubungan pekerjaan bebas tidak termasuk dalam objek pajak PP 46 Tahun 2013 ini.

Saran yang kedua adalah royalti, karena dianggap sebagai penghasilan pasif, maka seharusnya masuk PPh Pasal 4 ayat (2) yang final, seperti perlakuan kepada bunga deposito. Final artinya tidak dihitung lagi dalam penghasilan neto di akhir tahun, sehingga tidak perlu lagi dikenakan tarif pasal 17. Namun, saran ini masih perlu dikaji kembali karena besaran pajak yang harus dibayar tentu saja tergantung dengan besaran tarif yang dikenakan secara final. Bisa saja, pajak yang harus dibayar oleh penulis malah lebih tinggi dibandingkan dengan dipotong PPh pasal 23.

Saran yang ketiga adalah memasukkan royalti dalam penghasilan yang bisa dihitung melalui NPPN. Penulis keberatan apabila royalti yang sebenarnya adalah penghasilan utama mereka malah tidak dapat dihitung menggunakan NPPN. Sebenarnya saran ini yang telah diakomodasi oleh Surat Edaran SE-639/ PJ.03/2017 yang menyatakan bahwa penghasilan bruto dari pekerjaan bebas sebagai penulis meliputi semua penghasilan yang terkait dengan profesi penulis, termasuk royalti yang diterima dari penerbit dari hak cipta di bidang kesustraan yang dimiliki oleh penulis sehingga masuk dalam penghasilan yang dapat dikenai NPPN. Namun penjelasan terakhir dalam Surat Edaran SE-639/PJ.03/2017 menuliskan atas penghasilan dari hak cipta di bidang kesustraan berupa royalti dipotong PPh pasal 23 sebagai pelunasan PPh dalam tahun berjalan yang dapat dikreditkan terhadap PPh yang terutang untuk tahun pajak yang bersangkutan.

Berdasarkan saran-saran dan solusi yang dimaksud, maka diilustrasikan perhitungan PPh bagi profesi penulis. Misalnya, Penulis TR memperoleh penghasilan pada tahun 2016 sebagai pembicara, narasumber dan lain-lain sebesar Rp 800.000.000,-. Royalti yang diperoleh dari Penerbit sebesar Rp 500.000.000,- (belum dipotong PPh 23). Berapa PPh terutang TR jikadiasumsikan statusnya belum menikah dan tanpa tanggungan? 
Tabel 1. Perhitungan Pajak Penghasilan untuk Profesi Penulis

\begin{tabular}{|c|c|c|c|c|c|}
\hline & $\begin{array}{l}\text { Perhitungan } \\
\text { versi awal TR }\end{array}$ & $\begin{array}{l}\text { Tarif pajak 1\% } \\
\text { dan final }\end{array}$ & $\begin{array}{l}\text { Royalti : PPh } \\
23\end{array}$ & $\begin{array}{l}\text { Royalti masuk } \\
\text { NPPN }\end{array}$ & $\begin{array}{l}\text { Royalti masuk } \\
\text { PPh Final }\end{array}$ \\
\hline Penghasilan & 800.000 .000 & 800.000 .000 & 800.000 .000 & 800.000 .000 & 800.000 .000 \\
\hline Royalti & 500.000 .000 & 500.000 .000 & 500.000 .000 & 500.000 .000 & 500.000 .000 \\
\hline $\begin{array}{l}\text { Penghasilan } \\
\text { bruto }\end{array}$ & 1.300 .000 .000 & 1.300 .000 .000 & 1.300 .000 .000 & 1.300 .000 .000 & 1.300 .000 .000 \\
\hline $\begin{array}{l}\text { Penghasilan } \\
\text { neto }\end{array}$ & - & - & 900.000 .000 & 650.000 .000 & 400.000 .000 \\
\hline PTKP & 54.000 .000 & 54.000 .000 & 54.000 .000 & 54.000 .000 & 54.000 .000 \\
\hline PKP & 1.246 .000 .000 & 1.246 .000 .000 & 846.000 .000 & 596.000 .000 & 346.000 .000 \\
\hline PPh Terutang & & & & & \\
\hline $\begin{array}{l}5 \% \quad X \quad R p \\
50.000 .000,-\end{array}$ & 2.500 .000 & - & 2.500 .000 & 2.500 .000 & 2.500 .000 \\
\hline $\begin{array}{l}15 \% \quad \mathrm{X} \quad \mathrm{Rp} \\
200.000 .000,-\end{array}$ & 30.000 .000 & - & 30.000 .000 & 30.000 .000 & 30.000 .000 \\
\hline $\begin{array}{l}25 \% \quad \mathrm{X} \quad \mathrm{Rp} \\
250.000 .000,-\end{array}$ & 62.500 .000 & - & 62.500 .000 & 62.500 .000 & 24.000 .000 \\
\hline $\begin{array}{l}30 \% \quad \mathrm{X} \quad \mathrm{Rp} \\
\ldots \ldots \ldots \ldots \ldots \ldots\end{array}$ & 217.380 .000 & 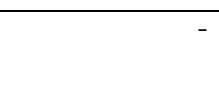 & 103.800 .000 & 28.800 .000 & - \\
\hline PPh Terutang & 312.380 .000 & - & 198.800 .000 & 123.800 .000 & 56.500 .000 \\
\hline Kredit Pajak & $(75.000 .000)$ & - & $(75.000 .000)$ & - & - \\
\hline PPh pasal 29 & 237.380 .000 & - & 123.800 .000 & - & - \\
\hline PPh final & - & 12.460 .000 & - & - & 75.000 .000 \\
\hline Total PPh & 312.380 .000 & 12.460 .000 & 123.800 .000 & 123.800 .000 & 131.500 .000 \\
\hline
\end{tabular}

Perhitungan table 1 menunjukkan bahwa memang saran penulis untuk memberlakukan tarif $1 \%$ dan final adalah yang paling menguntungkan untuk profesi penulis. Namun, perlu dicermati bahwa ini tidak sesuai dengan definisi penulis sebagai pekerjaan bebas. Apabila ini diberlakukan, bukan tidak mungkin profesiprofesi lain yang turut masuk dalam kategori pekerjaan bebas, akan ikut meminta perlakuan yang sama. Hal ini tentu perlu dikaji dengan pertimbangan yang masak. Saran yang kedua adalah memperlakukan royalti sebagai penghasilan yang dipotong $\mathrm{PPh}$ final. Namun, nyatanya setelah dihitung, dengan asumsi tarif final disamakan dengan tarif pasal 23, sebesar $15 \%$, menunjukkan bahwa sebenarnya total pajak penghasilan yang dibayar oleh penulis menjadi lebih tinggi dibandingkan yang lain. Saran yang ketiga, sesuai dengan Surat Edaran S-639/PJ.03/2017 sebenarnya paling ideal dilaksanakan karena sesuai dengan Ketentuan Umum Perpajakan serta jumlah pajak yang dibayar tentu tidak jauh berbeda dengan profesi dalam pekerjaa bebas lainnya.

\section{SIMPULAN}

Kecepatan informasi di jaman internet ini memang bagai pisau bermata dua. Informasi yang beredar, baik salah, kurang tepat maupun yang benar, dengan sangat cepat beredar. Informasi yang bermacam-macam menyebabkan netizen di dunia maya menjadi kurang berhati-hati dalam mempercayai sesuatu. Berita yang seringkali viral, biasanya lebih banyak dipercaya oleh masyarakat meskipun kebenarannya tentu dapat dipertanggunjawabankan.

Masalah pajak bagi profesi penulis telah menjadi viral sejak penulis terkenal Indonesia, TR, menulis catatan di laman facebook nya mengenai uneg-uneg hatinya mengenai perlakuan pajak bagi profesi penulis. Penulis DL ikut menuliskan masalahmasalah yang dihadapi oleh penulis dan juga memberikan solusi dari sudut pandang penulis. Beberapa solusi ditawarkan oleh penulis DL untuk menjawab kegelisahan profesi penulis mengenai pajak.

Penggunaan NPPN bagi pekerjaan bebas memang sudah tertuang pada Peraturan Direktur Jenderal Pajak Nomor PER-17/PJ/2015 tentang Norma 
Perhitungan Penghasilan Neto (NPPN). Profesi penulis memang memiliki hak menggunakan NPPN untuk menghitung Penghasilan Neto. Perhitungan menunjukkan sebenarnya tidak berbeda pemotongan Pajak Penghasilan $(\mathrm{PPh})$ pasal 23 untuk royalti ataupun saat royalti dapat dihitung dengan NPPN. Yang berbeda saat Royalti dipotong dengan PPh pasal 4 ayat (2) yang tentu saja tergantung dengan tarifnya. Perlakuan tarif final $1 \%$ rawan akan gesekan dengan dasar hukum dalam perpajakan serta gejolak dari profesi-profesi pekerjaan bebas lainnya.

Gerak cepat dari Menteri Keuangan dan Direktorat Jenderal Pajak merupakan sebuah solusi yang sangat tepat. Sri Mulyani segera merespon dan memberikan mandat kepada Dirjen Pajak untuk mengklarifikasi berita tersebut. Gerak cepat Dirjen Pajak juga terlihat dari dikeluarkannya siaran pers nomor 29/2017 pada tanggal 6 September 2017 diikuti dengan Surat Edaran S-639/PJ.03/2017 pada tanggal 7 September 2017. Penekanan pada pemberlakuan Norma Perhitungan Penghasilan Neto (NPPN) sebesar $50 \%$ bagi profesi penulis disampaikan kembali oleh Dirjen Pajak. Komunikasi kepada masyarakat melalui siaran pers maupun kepada Kepala Kantor Wilayah DJP menunjukkan bahwa Dirjen Pajak merespon keluhan dan masukan dari masyarakat. Bahkan, pada tanggal 14 September 2017 telah dilakukan pertemuan dialog antara Sri Mulyani selaku Menteri Keuangan, Bekraf dan Ditjen Pajak dengan penulis yang diikuti sampai 1000 hadirin untuk menerima masukan dari profesi penulis.

Proses perbaikan dunia perpajakan Indonesia memang masih melalui jalan yang panjang. Namun, usaha terus menerus harus tetap dilakukan. Dialog dan respon dari DJP merupakan salah satu upaya untuk memberikan kepuasan pada Wajib Pajak. DJP juga menunjukkan diri semakin terbuka terhadap masukanmasukan dari Wajib Pajak untuk perbaikan diri. Semoga seluruh upaya yang dilakukan dapat membangun "Budaya Sadar Membayar Pajak sebagi Bukti Cinta Tanah Air".

\section{DAFTAR RUJUKAN}

Direktorat Jenderal Pajak. 2009. Peraturan Dirjen Pajak Nomor PER-33/PJ/2009.

Direktorat Jenderal Pajak. 2013. Peraturam Pemerintah No 46 Tahun 2013.

Direktorat Jenderal Pajak. 2015. Peraturan Dirjen Pajak tentang Pedoman Teknis Tata Cara Pemotongan, Penyetoran dan Pelaporan Pajak Penghasilan Pasal 21.

Direktorat Jenderal Pajak. 2015. Peraturan Direktur Jenderal Pajak Nomor PER17/PJ/2015 tentang Norma Perhitungan Penghasilan Neto (NPPN).

Direktorat Jenderal Pajak. 2017. Surat Edaran SE-639/PJ.03/2017 Mengenai Perlakuan Pajak Penghasilan Wajib Pajak Orang Pribadi yang Memiliki Pekerjaan Bebas sebagai Penulis.

Erawati, T. \& A. M. W. Parera. 2017. Pengaruh Kesadaran Wajib Pajak, Sanksi Perpajakan, Pengetahuan Perpajakan dan Pelayanan Fiskus. Jurnal Akuntansi, Vol 5 No 1, halaman 37.

Lestari, D. 2017. Royalti dan Keadilan. Laman Facebook Pribadi: 7 September 2017

Liye, T. 2017. Jalan Keluarnya Selalu Ada. Laman Facebook Pribadi: 6 September 2017

Kementrian Keuangan Republik Indonesia. 2013. Undang-Undang KUP dan Peraturan Pelaksanannya. Jakarta

Sari, D.P. 2011. Persepsi Wajib Pajak terhadap Dunia Perpajakan Indonesia setelah kasus "Gayus Tambunan". Simposium Nasional Akuntansi XIV, IAIKompartemen Pendidik, 20-23 Juli 2011, Aceh

Yusdinar, dkk. 2015. Pengaruh Faktor-Faktor yang Mempengaruhi Kepatuhan Wajib Pajak dalam Melakukan Pembayaran Pajak Bumi dan Bangunan Perdesaan dan Perkotaan (Studi pada Wajib Pajak PBB-P2 Kecamatan Jombang Kabupaten Jombang). Jurnal Perpajakan (JE-JAK), Vol 1 No 1. 